\title{
SERVICE QUALITY CONCERNS OF FARMERS SELLING THEIR PROPERTY THROUGH REAL ESTATE AGENCIES
}

\author{
Lina Pilelienė, Audrius Šimkus \\ Vytautas Magnus University, Lithuania \\ lina.pileliene@vdu.lt
}

\begin{abstract}
In a period of economic prosperity, the real estate market is very active. The demand for real estate is causing the growth of prices, thus inducing people to sell their properties. As the easiest and often most convenient way of selling the property is partnering a real estate company, even 95 per cent of sales are provided through the mediation. However, the increasing demand in services is often leading to the decrease in service quality. It is worth mentioning that, while the amount of real estate agencies is increasing, service quality becomes the main competitive advantage for companies. In order to contribute to a body of knowledge on service quality, this research deals with a problem: what service quality is provided by real estate agencies to farmers selling their properties, and what service quality dimensions have to be improved. The research aims to establish the undermanaged dimensions of service quality obtained by Lithuanian farmers selling their property through real estate agencies. The determination of latter dimensions is crucial for real estate agencies achieving to successfully compete in the market of real estate in Lithuania. In order to reach the aim of the research, previously elaborated service quality models were analysed and adapted to a current research framework. The questionnaire survey was provided to establish a model of service quality real estate agencies expected by farmers selling their property. Finally, the four-dimensional REASQ model was established.
\end{abstract}

Key words: farmers, Lithuania, real estate, service quality.

\section{Introduction}

When consumers need specialized competences and assistance to deal with their problems, they often search for professionals of service provision in such areas as law, brokerage, medical care, and real estate (Le \& Supphellen, 2017). According to Azmi et al. (2015), property industry will never become static; therefore, real estate agencies are facing growing demand from both sides: sellers and buyers. According to data Ober-Haus (2019), the first half of 2018 in Lithuanian realty market was one of the most successful during the period of the last ten years. The intensifying competition in the property market is encouraging real estate organisations to seek for necessary competencies (Azmi et al., 2015). Srinivasan (2017) emphasizes that a typical intermediation process in real estate industry undergoes later stages, i.e. discovery, matching, transaction, and special services'. Being intermediaries between property sellers and people who are searching for properties, real estate agencies are often responsible for marketing the property, the negotiation process, and for signing the final contract (Le \& Supphellen, 2017). One of the ways of achieving business success in terms of gaining competitive advantage and maintaining corporate reputation is quality services (Baharum, Nawawi, \& Saat, 2009).

Service quality assessment is one of the significant evaluation tools used to understand consumers' needs and wants by analysing customer experience and satisfaction regarding the services provided (Ghotbabadi, Feiz, \& Baharun, 2015). The benefits of providing a better service to customers result in increased profitability of a company, more satisfied customers and their loyalty, customer retention and positive recommendations (Giese and Cote, 2000). Moreover, the research provided by Piscopo (2016) enabled concluding that a significant link between quality of services and corporate reputation exists. In case of entities that seek to have a service orientation, service quality is a key determinant of the company's success (Chiang \& Perng, 2018). According to Vassiliadis, Fotiadis, \& Piper (2013), in comparison to evaluation of product's quality, defining the service quality is a challenge. Explaining the phenomenon, Tuzovic (2009) directs that the 'intangibility' characteristic (according to the author, services have been defined in terms of four main characteristics: 'intangibility', 'heterogeneity', 'inseparability', and 'perishability') represents a problem of services evaluation by target consumers.

According to Baharum, Nawawi, \& Saat (2009), in the service industry, e.g. real estate management, quality and its perception are very important. Analysing the quality of services in the real estate brokerage area, Seiler (2004) notices that the ability to deal with customers and maintain their relationships through superior service quality is an obligatory for any business irrespective of the type of industry. McDaniel \& Louargand (1994) emphasize that perceptions of quality service and its components may differ between consumers and sellers. However, while service quality research is common in most industries, its roots in the real estate area are only starting to face the necessity to care about management of service quality (Seiler, 2004). According to Tuzovic (2009), research of service quality (also of e-service quality) can be found in such industries as financial services, 
banks, shopping, hotels and catering, automobile services, and medical services; however, in the sector of real estate the concern with service quality is still low. The analysis of scientific literature in the field enables noticing that not much has changed during the last years: service quality research in a field of real estate is still scarce.

Therefore, the scientific problem solved in the article is: what service quality is provided by real estate agencies to farmers selling their properties, and what service quality dimensions have to be improved.

In order to contribute to a scientific discussion on service quality, the object of the research is service quality provided by real estate agencies to farmers selling their property, and the aim is to establish the undermanaged dimensions of service quality obtained by Lithuanian farmers selling their property through real estate agencies. To reach the aim, following tasks were set for the research:

- To determine theoretically the dimensions of service quality specific in real estate industry;

- To discuss the determined dimensions with representatives of real estate agencies and farmers selling their properties through the agencies;

- To elaborate and test service quality assessment model specific to real estate industry;

- Provide managerial suggestion for real estate agencies working with farmers.

\section{Materials and Methods}

According to Ober-Haus (2019), in 2018 market activity for large plots of land for development was rather weak. The number of publicly traded transactions was much lower than for example in 2017. Land plots located in strategically attractive urban locations continue to attract building companies, but transactions are taking under consideration only such risk-inducing factors as general commercial outlook, residential real estate market, site location characteristics, land acquisition legal terms, etc. The slowing down of stable commercial rents or the rise in house prices is forcing a more conservative approach to land sales prices. However, the lack of bigger plots of land located in central parts of the city enables maintaining the existing level of prices of land. Land prices in main parts of cities or other areas attractive for housing or business development (with detailed plans or building permits) are between EUR 400 and EUR 1500 per $\mathrm{m}^{2}$ or about $300-1000$ euros per gross price, builds a $\mathrm{m}^{2}$ of residential or commercial premises. Plot prices in residential areas (with detailed plans or building permits) start from EUR 60 to 200 per $\mathrm{m}^{2}$; finally, it amounts to approximately EUR 70 - 200 per $\mathrm{m}^{2}$ of the total floor space to be built. In 2018 in the Vilnius region, only small positive changes occurred in the market of individual houses. In the last 5 years, there have been no major changes in the offering of land in the suburbs of Vilnius. Plots of land offered for the construction of living houses are supplied by either private individuals, or developers suggesting a complete package of land plots sold (liaison, access roads and any other prosperity). For this reason, buyers have enough good choices and negotiating power. At the end of the year 2018, the prices of private houses with partial or full finish in the suburbs of the lower cost were EUR $20-30$ per $\mathrm{m}^{2}$. Prices of land offered for agricultural purposes, depending on a district, land quality and plot, start from 1,000 up to 5,000 euros per ha (Table 1). Rental prices for agricultural land are shown in Table 2. According to the data provided by Central Register, in the year 2018, total volume of land transactions in Lithuania increased by more than $6 \%$. The activity of transactions in the Lithuanian land

Prices by types of agricultural land

Table 1

\begin{tabular}{|c|c|c|c|c|c|}
\hline \multirow{2}{*}{ Total area by purpose } & \multicolumn{5}{|c|}{ Prices by types of agricultural land | EUR per hectare (ha) } \\
\cline { 2 - 6 } & Y2013 & Y2014 & Y2015 & Y2016 & Y2017 \\
\hline Republic of Lithuania & 1956 & 2171 & 3025 & 3340 & 2163 \\
\hline Vilnius county & 1135 & 1313 & 2207 & 2787 & 1911 \\
\hline Alytus county & 813 & 1146 & 2081 & 2401 & 1789 \\
\hline Kaunas county & 3197 & 2863 & 3271 & 3957 & 2554 \\
\hline Klaipėda county & 1665 & 1538 & 3478 & 3137 & 2540 \\
\hline Marijampole county & 2200 & 3322 & 4014 & 4595 & 2827 \\
\hline Panevėžys county & 1885 & 2839 & 3087 & 3575 & 2130 \\
\hline Šiauliai county & 2334 & 3476 & 3333 & 3299 & 2880 \\
\hline Tauragé county & 1819 & 2131 & 2470 & 2741 & 2093 \\
\hline Telšiai county & 1323 & 1755 & 2375 & 2624 & 2504 \\
\hline Utena county & 1125 & 982 & 1533 & 1835 & 1701 \\
\hline
\end{tabular}


Rent price of agricultural land

\begin{tabular}{|c|c|c|c|c|c|}
\hline \multirow{2}{*}{ Total area by purpose } & \multicolumn{5}{|c|}{ Rent price of agricultural land | EUR per hectare (ha) } \\
\cline { 2 - 6 } & Y2013 & Y2014 & Y2015 & Y2016 & Y2017 \\
\hline Republic of Lithuania & 78 & 80 & 80 & 81 & 99 \\
\hline Vilnius county & 45 & 58 & 74 & 78 & 74 \\
\hline Alytus county & 41 & 69 & 64 & 70 & 47 \\
\hline Kaunas county & 93 & 82 & 81 & 99 & 92 \\
\hline Klaipèda county & 50 & 74 & 87 & 99 & 67 \\
\hline Marijampolė county & 93 & 95 & 109 & 84 & 80 \\
\hline Panevėžys county & 69 & 77 & 93 & 64 & 91 \\
\hline Šiauliai county & 82 & 91 & 76 & 99 & 160 \\
\hline Tauragé county & 56 & 72 & 43 & 40 & 72 \\
\hline Telšiai county & 72 & 89 & 79 & 72 & 100 \\
\hline Utena county & 59 & 59 & 70 & 66 & 75 \\
\hline
\end{tabular}

market in 2018 was very high and exceeded 20152017. It was $12 \%$ on average in 2018 . The growth of land-related transactions in the Vilnius region was not so rapid, but the indicators are well above 2014-2016. Total number of land transactions in Vilnius in 2018 increased by $4 \%$ to 495 per month. In the county of Vilnius, all land transactions increased by $2 \%$ in 2018.

The efficiency of agricultural activity in Lithuania is increasing. Recently, agricultural investment in buildings, vehicles and machinery has grown rapidly. Accordingly, the need to have more workers on the farm has decreased, so their number has been decreasing, and the farms themselves are gradually increasing. All this shows modernization of Lithuanian agriculture. The available technical capacity allows for more efficient use of farmland and more income from agricultural activities. Although a large part of farmers' investments are still in agricultural machinery, machinery and vehicles, the data show that since 2009, there has been a decline in the number of farmers. The share of investments for land acquisition is constantly increasing. There is a growing need for farmers to grow, to have more land. The technical capacity currently available to farmers is unlikely to be fully utilized. For example, large investments in the upgrading of technology and productive capacity may be hampered by a lack of land or limited amount of activity. Therefore, there is a need for farmers to increase their existing land holdings, and the demand for land or its rent rises as demand increases.

In order to solve the problem of the research and reach the aim, service quality dimensions have to be established. Many models of service quality assessment can be found in scientific literature. The most famous model used to evaluate quality of services is SERVQUAL (proposed by Parasuraman, Zeithaml, \& Berry, 1988). In this model, 22 items reflecting the dimensions of service quality were provided: tangibles, reliability, responsiveness, assurance, empathy. The model was extensively applied in service industry irrespective of services kind. Therefore, it can be stated that using a general model in specific services industry might lead to abstract results. Achieving to obtain more precise and industry-specific results, a model has to be adapted. The most famous attempt to model quality of services in the industry of real estate was elaboration of RESERV (abbreviation of Real estate SERVice quality) proposed by Nelson \& Nelson (1995). According to the authors, SERVQUAL was not a realistic instrument to be used as a mean of identifying and contacting recent clients of real estate brokerage firms. The RESERV scale contains more dimensions in comparison to SERVQUAL, two dimensions were added: professionalism and availability. Considering the trend that in twenty first century many service providers have transferred their activity to the internet, Parasuraman, Zeithaml, \& Malhotra (2005) suggested a 22-item E-S-QUAL scale of such dimensions as: efficiency; fulfilment; system availability; and privacy; and its 11-item subscale E-RecS-QUAL, containing three dimensions focussed on handling problems with services and inquiries: responsiveness, compensation, and contact. E-S-QUAL is the mostly applied scale for measuring quality of e-service (Gedik \& Etlioğlu, 2018); therefore, it can be also applied in a framework of real estate services. Another attempt to elaborate a methodology for service quality measurement in real estate industry was by Chiang \& Perng (2018). Authors suggested an innovative model for the improvement of service quality in the property management industry, which combined the SERVQUAL with Kano and the Refined Kano models. Therefore, general service quality dimensions 
The final composition of question-form

\begin{tabular}{|l|l|l|}
\hline \multicolumn{1}{|c|}{ Scale (source) } & \multicolumn{1}{|c|}{ Dimension } & \multicolumn{1}{c|}{ Items in original scale } \\
\hline \multirow{4}{*}{$\begin{array}{l}\text { RESERV (Nelson \& Nelson, } \\
\text { 1995) }\end{array}$} & Tangibles & TANG1; TANG3 \\
\cline { 2 - 3 } & Reliability & REL2; REL3 \\
\cline { 2 - 3 } & Responsiveness & RESP1; RESP2; RESP3 \\
\cline { 2 - 3 } & Assurance & ASSUR1; ASSUR2; ASSUR3 \\
\cline { 2 - 3 } & Empathy & EMPA1; EMPA2; EMPA3; EMPA4 \\
\cline { 2 - 3 } & Professionalism & PROF1; PROF2; PROF3; PROF5; PROF6 \\
\cline { 2 - 3 } & Availability & AVAI; AVAI2; AVAI3; AVAI4; AVAI6 \\
\hline \multirow{4}{*}{$\begin{array}{l}\text { SERVQUAL (Parasuraman, } \\
\text { Zeitham1, \& Berry (1988) }\end{array}$} & Tangibles & E3 \\
\hline \multirow{2}{*}{$\begin{array}{l}\text { E-S-Qitham1, \& Malhotra, 2005) } \\
\end{array}$} & Efficiency & EFF1; EFF2; EFF3; EFF4; EFF5; EFF6; EFF7; EFF8 \\
\cline { 2 - 3 } & System Availability & SYS2; SYS3; SYS4 \\
\cline { 2 - 3 } & Privacy & PRI1 + PRI2 (mixed answer) \\
\cline { 2 - 3 } & Contact & CON1; CON2; CON3 \\
\hline
\end{tabular}

(expanded into 32-item scale) were categorized as: A-Attractive; M-Must be; O-One-dimensional; and I-Indifferent. Further applying The Refined model of Kano authors introduced such attributes as HA-Highly attractive and LA-Less attractive; the $\mathrm{M}$ category was divided into $\mathrm{C}$-Critical and N-Necessary; the $\mathrm{O}$ category into HV-High value-added and LV-Low value added; finally, the I category was divided into

Eigenvalues and their rotation

Table 4

\begin{tabular}{|c|c|c|c|c|c|c|}
\hline \multirow{2}{*}{ Component } & \multicolumn{3}{|c|}{ Initial Eigenvalues } & \multicolumn{3}{|c|}{ Rotation } \\
\hline & Total & Variance & Cumulative & Total & Variance & Cumulative \\
\hline 1 & 10.501 & 47.730 & 47.730 & 4.424 & 20.110 & 20.110 \\
\hline 2 & 1.569 & 7.131 & 54.861 & 4.130 & 18.772 & 38.882 \\
\hline 3 & 1.181 & 5.368 & 60.229 & 2.968 & 13.489 & 52.371 \\
\hline 4 & 1.094 & 4.973 & 65.202 & 2.823 & 12.831 & 65.202 \\
\hline 5 & 0.927 & 4.213 & 69.414 & - & - & - \\
\hline 6 & 0.782 & 3.553 & 72.968 & - & - & - \\
\hline 7 & 0.688 & 3.129 & 76.097 & - & - & - \\
\hline 8 & 0.655 & 2.978 & 79.075 & - & - & - \\
\hline 9 & 0.603 & 2.743 & 81.817 & - & - & - \\
\hline 10 & 0.561 & 2.551 & 84.368 & - & - & - \\
\hline 11 & 0.529 & 2.404 & 86.772 & - & - & - \\
\hline 12 & 0.505 & 2.294 & 89.066 & - & - & - \\
\hline 13 & 0.425 & 1.932 & 90.999 & - & - & - \\
\hline 14 & 0.350 & 1.593 & 92.592 & - & - & - \\
\hline 15 & 0.320 & 1.455 & 94.047 & - & - & - \\
\hline 16 & 0.280 & 1.272 & 95.319 & - & - & - \\
\hline 17 & 0.255 & 1.159 & 96.478 & - & - & - \\
\hline 18 & 0.202 & 0.920 & 97.398 & - & - & - \\
\hline 19 & 0.196 & 0.892 & 98.289 & - & - & - \\
\hline 20 & 0.151 & 0.688 & 98.977 & - & - & - \\
\hline 21 & 0.129 & 0.588 & 99.565 & - & - & - \\
\hline 22 & 0.096 & 0.435 & 100.000 & - & - & - \\
\hline
\end{tabular}


P-Potential and CF-Care-free. However, the research was provided in a framework of property management, not of agencies' services.

Achieving to elaborate a measurement model adapted to a framework of real estate agencies and determine the dimensions of quality of services specific to real estate market, all the presented models were analysed and discussed with representatives of real estate agencies and farmers (selling their properties with the help of agencies) to compose a situationspecific questionnaire. After a thorough analysis of the model, it was decided that RESERV duplicates the main questions of SERVQUAL; therefore, the SERVQUAL questionnaire was eliminated from further analysis. The two questionnaires: RESERV and E-S-QUAL were analysed by the experts to compose a scale for real estate agencies' service quality for farmers. After evaluation, the newly elaborated questionnaire included 25 questions from RESERVE (one of those from original SERVQUAL, which was eliminated from RESERV; and one newly composed by unifying two statements from RESERV scale) and 15 items from E-S-QUAL scale (including all 3 items reflecting 'Contact' dimension of E-RecSQUAL). The items from Kano model were not included to the questionnaire, in order to maintain simplicity for respondents: the Kano model's essence is different in comparison to other three; therefore, additional mental efforts might be needed to complete the evaluation. The final composition of the questionform is provided in Table 3 .

The questionnaire survey was provided in February, 2019; the research sample was 106 farmers intending to sell their property (land or forest) through a well-known Lithuanian real estate agency (having 22 subdivisions in Lithuania). Selected farmers had to indicate the service quality level they expected from the real estate agency by rating the items in 5-point Liker type (1 - absolutely unnecessary; 2 - unnecessary; 3 - unobtrusive; 4 - necessary; 5 - obligatory).

The obtained answers were analysed with IBM SPSS Statistics v.20 software.

\section{Results and Discussion}

In order to elaborate the reliable scale for real estate agencies service quality measurement-REASQ scale, the reliability analysis was provided. Following the example of Chiang \& Perng (2018), 18 statements having lowest Cronbach's $\alpha$ were removed from

\section{Communality results}

\begin{tabular}{|c|c|c|}
\hline Item & Initial result & Extraction \\
\hline REASQ1 & 1.00 & 0.535 \\
\hline REASQ2 & 1.00 & 0.499 \\
\hline REASQ3 & 1.00 & 0.662 \\
\hline REASQ4 & 1.00 & 0.767 \\
\hline REASQ5 & 1.00 & 0.650 \\
\hline REASQ6 & 1.00 & 0.767 \\
\hline REASQ7 & 1.00 & 0.625 \\
\hline REASQ8 & 1.00 & 0.446 \\
\hline REASQ9 & 1.00 & 0.723 \\
\hline REASQ10 & 1.00 & 0.693 \\
\hline REASQ11 & 1.00 & 0.614 \\
\hline REASQ12 & 1.00 & 0.622 \\
\hline REASQ13 & 1.00 & 0.821 \\
\hline REASQ14 & 1.00 & 0.734 \\
\hline REASQ15 & 1.00 & 0.730 \\
\hline REASQ16 & 1.00 & 0.688 \\
\hline REASQ17 & 1.00 & 0.659 \\
\hline REASQ18 & 1.00 & 0.698 \\
\hline REASQ19 & 1.00 & 0.600 \\
\hline REASQ20 & 1.00 & 0.583 \\
\hline REASQ21 & 1.00 & 0.732 \\
\hline REASQ22 & 1.00 & 0.498 \\
\hline & & \\
\hline & & \\
\hline
\end{tabular}


REASQ instrument

\begin{tabular}{|c|c|c|}
\hline $\begin{array}{c}\text { REASQ } \\
\text { dimension }\end{array}$ & Item & Statement \\
\hline \multirow{8}{*}{$\begin{array}{l}\text { Professio- } \\
\text { nalism }\end{array}$} & PROF1 & Real estate offices should be conveniently located \\
\hline & PROF2 & Real estate agents should dress in a professional manner \\
\hline & PROF3 & Real estate agency should be dependable \\
\hline & PROF4 & The commission or fee charged should be in keeping with services provided \\
\hline & PROF5 & Real estate agents should be knowledgeable \\
\hline & PROF6 & Real estate agents should always be willing to help clients \\
\hline & PROF7 & Real estate agency should respond to client requests promptly \\
\hline & PROF8 & Clients should not have to wait to get appointments with real estate agents \\
\hline \multirow[t]{6}{*}{ Trustfulness } & TRUST1 & Real estate agencies should tell clients exactly when services will be performed \\
\hline & TRUST2 & Real estate agencies should keep clients informed about matters of concern to them \\
\hline & TRUST3 & Client should feel safe in their transactions with real estate agents \\
\hline & TRUST4 & Clients' dealings with real estate agencies should be pleasant \\
\hline & TRUST5 & Real estate agents should make every effort to understand the needs of their clients \\
\hline & TRUST6 & Real estate agencies should protect their clients' interest and wellbeing \\
\hline \multirow{4}{*}{$\begin{array}{l}\text { Online } \\
\text { convenience }\end{array}$} & ONCON1 & It should be easy to find the information in real estate agency's website \\
\hline & ONCON2 & Real estate agency's website should enable to complete transactions quickly \\
\hline & ONCON3 & Information in real estate agency's web-site should be well organized \\
\hline & ONCON4 & Real estate agency's website should load pages fast \\
\hline \multirow{4}{*}{$\begin{array}{l}\text { Online } \\
\text { reliability }\end{array}$} & ONRE1 & Real estate agency's website does not crash \\
\hline & ONRE2 & Real estate agency's website should protect personal information \\
\hline & ONRE3 & Real estate agency's website should have service representatives available online \\
\hline & ONRE4 & Real estate agents should be available at hours convenient to their clients \\
\hline
\end{tabular}

the questionnaire (the reliability level was 0.500). Therefore, 22 items (overall Cronbagh's $\alpha=0.942$ ) in the questionnaire remained for the analysis.

As the questionnaire was given for respondent evaluation without the indication of particular dimensions, factor analysis was provided to determine the structure of real estate agencies' service quality. Analysing the results, the KMO score was higher than $0.5(0.901>0.5)$ and the Bartlett's criterion's sig. was 0.000 . Therefore, data were considered as reliable and suitable to provide factor analysis. After calculating and rotating the Initial Eigenvalues, four factors were established in the questionnaire (Table 4).

After component rotation, four factors define more than $65 \%$ of variance. All the communalities are higher than 0.2 (Table 5); therefore, all 22 items of the questionnaire can be used in further analysis of real estate agencies service quality.

As the dimension reduction analysis shows, all 22 analysed items can be grouped to reflect four real estate agencies' service quality dimensions. As the initial questionnaire was composed of three previously elaborated questionnaires, its adaptation to the conditions of Lithuanian real estate agencies market leads to regrouping of items and renaming the dimensions. The final instrument for the assessment of service quality provided by real estate agencies to farmers selling their properties and the evaluation of items is provided in Table 6.

After grouping all items of the questionnaire to represent particular dimensions of service quality, their evaluations by respondents in terms of necessity has to be evaluated to provide managerial guidelines for real estate agencies working with farmers. As all items in the questionnaire were evaluated by respondents in 5-point Likert scale, the evaluation mean calculation is provided to obtain a holistic picture of the model. The dimensions' evaluation means are provided in Figure.

As shown in Figure 1, the most important service quality dimension for farmers selling their property through real estate agencies is online convenience. Considering the results there might be presumed that before directly contacting the real estate agency farmers are searching for the information about services, pricing and other service-related matters. Therefore, a proper management of online websites should become a distinct concern of real estate agencies. Moreover, real estate agency's website has to be clear and work 


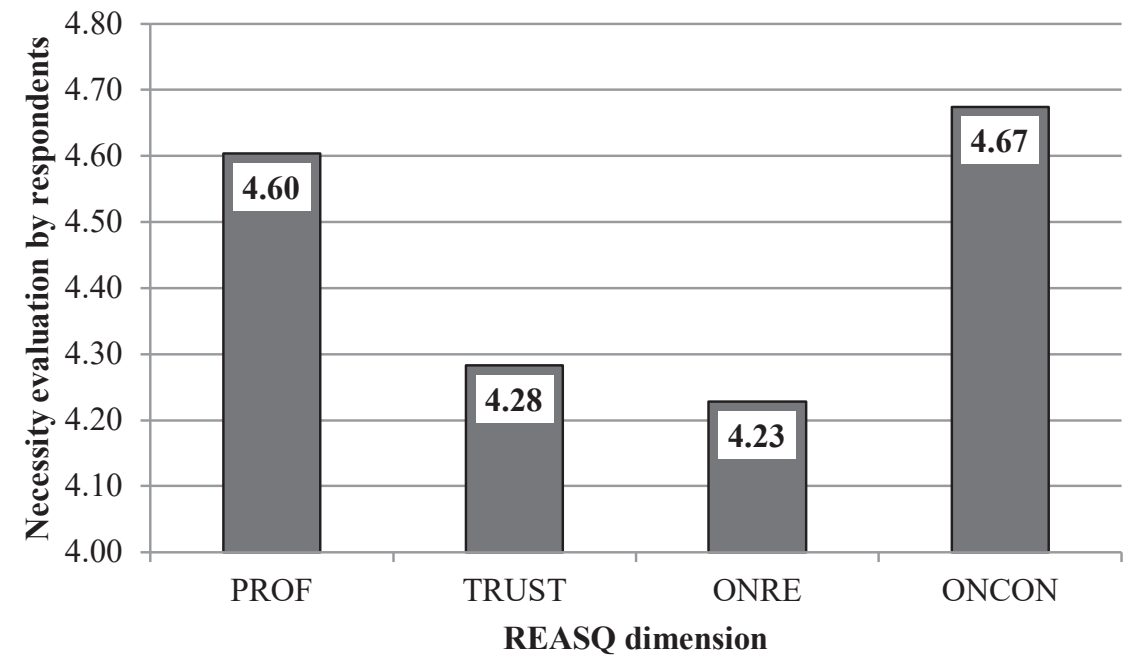

Figure 1. The evaluations of REASQ dimensions by farmers.

fast. The second very important dimension for farmers is real estate agency's professionalism. According to the results, this dimension encompasses visual appearance of the office and the staff, also, knowledge and fast pace of agents.

The two remaining real estate agencies' service quality dimensions were also evaluated as being more than necessary, but not close to obligatory.

\section{Conclusions}

The analysis of scientific literature related to service quality management enables noticing that extensive researches are being provided in various industries. However, when it comes to the real estate industry, the research is scarce. Several researches can be found related to real estate services management; however, none of them provides direct guidelines for the real estate agencies on how to properly assess their service quality.

In order to provide service quality research in real estate industry, a company can apply each of the models (i.e. SERVQUAL, E-S-QUAL, or RESERV), and the results will be obtained. However, if a company is achieving to get competitive advantage in the market, more precise service quality research is needed. The research provided in a framework of the services provided by real estate agencies encompassed the dimensions from all three analyzed models. The research results enabled the elimination of unimportant items from the scale; therefore, the newly elaborated scale can be applied in further research to better understand quality standards in the field of services provided by real estate agencies.

After adapting the existing questionnaires in a framework of real estate agencies' services provided to farmers, selling their property, four dimensions of service quality emerged. The dimensions were called: Professionalism, Trustfulness, Online Convenience, and Online Reliability. After analysing the respondent (farmers selling their property through real estate agencies) evaluations, the results showed that the most important dimensions were Online Convenience and Professionalism. Based on latter results it can be concluded that the importance of the Internet is obvious. Real estate agencies have to acknowledge that their customers (farmers in this case) are expecting to obtain many services online, without leaving their home. Online Convenience appeared to be the most important service quality dimension for farmers. Therefore, proper attention has to be paid to website creation and its maintenance. Another service quality dimension indicated as obligatory by farmers selling their property through real estate agencies was found to be Professionalism. Therefore, real estate agencies should also invest into their image by demonstrating their experience, intelligence and Know-How to consumers. Research results show that even visual appearance of the agency and its employees contributes to create the image of professional services.

The other two dimensions of real estate service quality - Trustfulness and Online Reliability - were considered as necessary but not obligatory. These dimensions can be considered as derivative: if Online Convenience and Professionalism is fulfilled, Trustfulness and Online Reliability also will be obtained.

By acknowledging the results obtained from the study, real estate agencies providing their services to farmers can easily improve their service quality and gain the image of professional and trustful companies. However, service quality research has to be performed constantly in order to monitor the changes in market needs and requirements regarding the quality. Also, the provided and approved questionnaire of REASQ can be used as a tool for company benchmarking and importance-performance analysis. 


\section{References}

1. Azmi, A.Sh.M., Nawawi, A.H., Ab Latif, S.N.F., \& Ling, N.L.F.J. (2015). Knowledge Management Obstacles in Real Estate (Valuation) Organisations: Towards Quality Property Services. Procedia - Social and Behavioral Sciences, 202(22), 159-168. DOI: 10.1016/j.sbspro.2015.08.219.

2. Baharum, Z.A., Nawawi, A.H., \& Saat, Z.M. (2009). Assessment of Property Management Service Quality of Purpose Built Office Buildings. International Business Research, 2(1), 162-174.

3. Chiang, T.-Y., \& Perng, Y.-H. (2018). A New Model to Improve Service Quality in the Property Management Industry. International Journal of Strategic Property Management, 22(5), 436-446. DOI: 10.3846/ijspm.2018.5226.

4. Gedik, H., \& Etlioğlu, M. (2018). Real Estate Marketing on the Internet. International Periodical for the Languages, Literature and History of Turkish or Turkic, 12(32). 79-94. DOI: 10.7827/TurkishStudies.12503.

5. Ghotbabadi, A.R., Feiz, S., \& Baharun, R. (2015). Service Quality Measurements: A Review. International Journal of Academic Research in Business and Social Sciences, 5(2), 267-286. DOI: 10.6007/IJARBSS/ v5-i2/1484.

6. Giese, J.L., \& Cote, J.A. (2002). Defining Consumer Satisfaction. Academy of Marketing Science. Retrieved March 3, 2019, from http:/www.proserv.nu/b/Docs/Defining\%20Customer\%20Satisfaction.pdf.

7. Le, N.Q., \& Supphellen, M. (2017). Determinants of repurchase intentions of real estate agent services: Direct and indirect effects of perceived ethicality. Journal of Retailing and Consumer Services, 35, 84-90. DOI: 10.1016/j.jretconser.2016.12.006.

8. McDaniel, J.R., \& Louargand, M.A. (1994). Real Estate Brokerage Service Quality: An Examination. Journal of Real Estate Research, 9(3), 339-352.

9. Nelson, S.L., \& Nelson, Th.R. (1995). RESERV: An Instrument for Measuring Real Estate Brokerage Service Quality. Journal of Real Estate Research, 10(1), 99-114.

10. Ober-Haus (2019). Real estate market report 18. Retrieved March 3, 2019, from http://www.ober-haus. com/real estate-market-report-2018.

11. Parasuraman, A., Ziethaml, V., \& Berry, L.L. (1988). SERVQUAL: A Multiple- Item Scale for Measuring Consumer Perceptions of Service Quality. Journal of Retailing, 62(1), 12-40.

12. Parasuraman, A., Zeithaml, V.A., \& Malhotra, A. (2005). E-S-QUAL: A Multiple-Item Scale for Assessing Electronic Service Quality. Journal of Service Research, 7(X), 1-21. DOI: 10.1177/1094670504271156.

13. Piscopo, I. (2016). Is there a Link between Service Quality and Corporate Reputation in the Real Estate Business in Malta? A Study of the Real Estate Business and the Perceptions of its Customers. Doctoral dissertation, University of Malta, Malta.

14. Seiler, V.L. (2004). Examining service quality for homebuyers in the residential real estate brokerage industry. Doctoral dissertation, Western Sidney University, Australia.

15. Srinivasan, R. (2017). Organising the Unorganised: Role of Platform Intermediaries in the Indian Real Estate Market. IIMB Management Review, 29(1), 58-68. DOI: 10.1016/j.iimb.2016.12.001.

16. Tuzovic, S. (2009). Key Determinants of Real Estate Service Quality among Renters and Buyers. Journal of Services Marketing, 23(7), 496-507. DOI: 10.1108/08876040910995284.

17. Vassiliadis, Ch.A., Fotiadis, A., \& Piper, L.A. (2013). Analysis of Rural Tourism Websites: the Case of Central Macedonia. Tourismos: An International Multidisciplinary Journal of Tourism, 8(1), 247-263. 